\title{
Shaping Students' Character through Edutainment Strategies
}

\author{
Tutuk Ningsih ${ }^{1 *}$
}

Desi Wijayanti Ma'rufah ${ }^{1}$

Risdianto Hermawan ${ }^{1}$

M. Sugeng Sholehuddin ${ }^{2}$

\author{
Siti Fatimah ${ }^{3}$ \\ ${ }^{1}$ Faculty of Education and Teacher Training, UIN Prof. KH. \\ Saifuddin Zuhri Purwokerto, Jl. A. Yani No.4oA, Karanganjing, Purwanegara, \\ Kec. Purwokerto Utara, Kabupaten Banyumas, Jawa Tengah 53126, Indonesia \\ ${ }^{2}$ Faculty of Tarbiya and Teacher Training, IAIN Pekalongan, \\ Jl. Kusuma Bangsa No.9, Panjang Baru, Pekalongan Utara, \\ Kota Pekalongan, Jawa Tengah 51141, Indonesia \\ ${ }^{3}$ Postgraduate Program, IAIN Syekh Nurjati Cirebon, Jl. Perjuangan, Sunyaragi, \\ Kec. Kesambi, Kota Cirebon, Jawa Barat 45132, Indonesia \\ ${ }^{*}$ Corresponding Author
}

DOI: https://doi.org/10.36941/jesr-2021-0138

\section{Abstract}

This study aims to describe and to analyze how creative school shapes the character of students through edutainment strategies. Character building is very important so the school need to design the curricula to develop students' character. Creative schools can use edutainment strategies to shape students' character, which provide enjoyable learning process. This qualitative-descriptive study used interviews, observation, and documentation for collecting the data which are analyzed qualitatively. The results show that the school as a creative school with edutainment-based character building, designed innovative ideas involving various activities namely, 1) Tilawah and Tahfidz (recitation and memorization of) Qur'an that formed character of religious and likes to read; 2) multiple language program that built friendly, communicative, responsible, and disciplined students; 3) computer education that developed creative and curious; 4) outdoor learning that included the character values: responsible and care for the environment; 5) leadership and entrepreneurship that resulted the students to be responsible, independent, disciplined, socially caring, and honest; 6) inviting native speakers that created the character of friendly and communicative.

Keywords: creative school, character, students, edutainment strategies

\section{Introduction}

Education is considered to be the most important aspect of nurturing students as the nation's successors; therefore, success in developing a learning model has become the primary goal of 
education in every country not to mention in Indonesia. Musthan (2019) states that through education, human potential is developed and human community will be empowered. School is a platform education and learning, and it holds an essential role in shaping the characters of students. In addition, Nurhayati (2017) proves that school as a formal institution plays an essential role as a place for socialization, helping develop students' personalities in relation to the vital role of building self-concepts. To create a fun and creative school are inseparable from the role of all school community, namely the principal, teachers, employees, students, stakeholders, and student guardians who work together in promoting the formation of student characters through edutainment strategies. Consequently, the school must continuously produce innovative and creative ideas to ensure a childfriendly and fun learning process. As stated by Kurniawan (2016:6), because school is a place of learning, care must be taken on whether the learning process is following children's expectations. An enjoyable school is the hope of both parents and students in which these creative schools are supported by teacher competence.

For learning, the school environment must be enjoyable for children, one of which is through fun facilities and proper infrastructure. However, in reality, there are still children who are too lazy to learn; children who are too spoiled; children who always bother their friends and tend to desire to play instead of learning. Therefore, the school must work hard to solve students' problems, so that the school can create a pleasant atmosphere; particularly the principal, the teachers and school environment should support the students in order to make students can feel at home in school, or school becomes a comfortable place with a homely environment. Forming student characters with edutainment strategies will then become very easy because character building starts at home, and creative schools create ideas for shaping students' characters with fun strategies; so that, when building the students character at school, the students do not have a burden of rules.

Furthermore, character education is believed as an important aspect for children at the early stage of school. The educational systems of world spectrum decide that the values of character should be embedded in every level of education because this forms children character that will be brought for the future (Choli \& Raihan, 2020; Tirri, 2009; Agboola \& Tsai, 2012). Similarly, Asmani (2011) said that the human character is the most critical aspect of the triumph of human kindness in the future. Strong student character will form a strong mentality, and strong mentality will give birth to strong motivation for struggling in their life.

To form student character, schools must become creative and fun, so students do not experience boredom in the learning process and can develop their talents with the teacher's guidance. As stated by Herpratiwi et al (2018), schools and colleges need to develop their own curricula to improve students' character. Farida and Rois (2014) asserted that a pleasant school involves parents (and the community) as a source and learning partner. Parental assistance is needed because, at home, children's education is the responsibility of parents. Schools, communities, and families must work together to help children become learners in a fun and exciting culture. To support this, a learning strategy that makes children happy is needed, so learning objectives are achieved, and learning materials are delivered following the curriculum used by the school. As said by Saripudin and Isnaeni (2018: 129), a strategy that is in accordance with the concept of a creative school is the edutainment strategy. Because edutainment is one of the fun learning processes that can make students feel at home and provide entertainment, students are happy and assume learning is no longer something that is frightening for them.

Moreover, as a learning technique, edutainment gives many benefits such as engaging students in an informal and inexpensive way and utilizing technology as an easy and efficient learning media (Corona et al., 2011). Besides, edutainment engages the students, increases student motivation in learning, provides meaningful learning experience and encourages students to study and apply more knowledge because edutainment uses various stimuli e.g. pictures, sounds and also characters that make students keep the knowledge in their deep memory (Gagne, cited in Backhaus \& Liff, 2007). In conclusion, edutainment gives many a for succeeding teaching and learning process and building student character at school. 
Several previous studies (Kusmarini et al., 2016; Rofiah, 2014; Rusydi, 2017) had already discussed the implementation of edutainment strategy at Elementary School. Most of the research focused on the use of edutainment for teaching the subject. However, there are limited discussions to study about using edutainment for building students' characters at school. Thus, the present study was an attempt to fill the gap.

This study was conducted at NU MASTER Elementary School of Sokaraja, Purwokerto, Banyumas Regency because the school uses a creative and fun school concept in the learning process; (1) a two-way social interaction of the school community, and (2) the characters of elementary school students are relatively still easily formed. The school has both excellences in the academic and nonacademic fields. Accordingly, this study aimed to describe and analyze how creative school shape students' character through edutainment strategies in NU MASTER Elementary School.

\section{Literature Review}

\subsection{Creative School}

Creative school has been defined by some experts. Firstly, according to Nurhayati (2017), creative school involves school community that develops new and different programs; and implements a creative approach that support students to increase their achievement and reduce the gap of students' achievement. In particular, Nurhayati (2017) explains that creative schools include: (1) aspects of the design of a creative approach, namely by involving all components such as staff, families and communities to support creative school, building rationalization with the support of data to construct the design of creative school, creating programs that are maintained by the school, identifying the design plans to improve student achievement, identifying the program in detail by deciding clear criteria as the program objectives, and developing instrument by school decision; (2) the community aspect that begins with the broad participation of parents and community members in developing designs, namely by collaborating staff, parents and community members to participate in designing the program and evaluating the result; and by collaborated with staff to identify the leadership and governance structures for schools; (3) staff aspect that work optimally through supporting all the designed programs, collaborating with the parents and communities to determine how staff, parents and community members will participate in program design and work, and collaborating with families and communities to identify leadership and governance for schools.

In addition, Anna, Suhud and Edis (2014) state in a creative school, the school hold the parents as learning resources and partners because parents had responsibility in their children's education through parental assistance. Meanwhile, schools and the community are only partners to guide children becoming whole individuals. Besides, the creative school should provide learning as a tradition that is interesting and fun. Thus, collaboration between school, parents and the community makes parents understand the curriculum, school activities and can provide more active advice and input than that parents and the community are expected.

\subsection{Edutainment Concept}

Edutainment now become a strategy that is popularly conducted at schools. Various concept of edutainment has been explained by some authorities. Pangastuti (2014:60) and Makarius (2016) defines that edutainment is stating for "education plus entertainment" which can be inferred as a program of education or training integrating entertainment in the learning process so that the students feel unconscious in grasping the value of the lesson. Moreover, Hamruni (2013) states that the main concept of edutainment is providing learning in a fun way, namely by putting games and humor into the teaching and learning process, by providing role plays, or using multi-media and demonstration in the classroom. The purpose of edutainment is to create the learning environment for making students have joyful and enjoyable learning experience so that the students will be 
interested in learning (Hamruni, 2013; Katsaliaki \& Mustafee, 2014). In short, by when the inner student motivation is grown up, their self-esteem in studying will be very helpful to make them feel enjoy in the learning environment.

\subsection{Character Building}

Nowadays, character building is more concerned in the educational aspect. Firstly, the term character will be defined by several experts. According to Lickona (1991), character is a person's natural trait in responding to situations morally which shows real action, namely good, honest, responsible behavior, respecting others, and other noble characters. In addition, Kesuma (2010) states that character is associated with temperament which gives him a definition that emphasizes the psychosocial elements associated with education and environmental context. To conclude, character is a way of thinking, behaving, and acting which becomes the characteristic of a person who becomes a habit and is displayed in community life (Ningsih, 2020). Inculcating values to school members means that character education will only be effective if students, teachers, school principals, and noneducators in schools are involved in character education practices. Finally, character education can be interpreted as value education, moral education, personality education which aims to develop students' abilities to make good or bad decisions, nurture what is good, maintain what is good and realize that good in everyday life by wholeheartedly.

\section{Methods}

The aim of this study is to describe how a creative school shapes the characters of students through edutainment strategies. To achieve this aim, a descriptive qualitative method was employed. The respondents of this research were the principal and two teachers at NU Master Elementary School Sokaraja, Banyumas Regency, Indonesia. In addition, this study used interview, observation and documentation for collecting the data. The interview was intended to seek the programs of creative school in shaping student character through edutainment strategies at the school. Then, the observation was conducted to perceive the learning activities and environment which develop students' characters in this creative school and to support the interview result. Besides, documentation was also used to support interview and observation result. Thus, triangulation of data collection techniques and sources of the data is an attempt to validate the data. Finally, the data of interview, observation and documentation were analyzed qualitatively using Miles \& Huberman theory. According to Miles \& Huberman, cited in Sugiono (2011), activities in qualitative data are carried out interactively and continue continuously to completion, so that the data is saturated. Thus, the collected data were categorized, reduced, displayed, and concluded. All the data from observation and interview were transcribed, and then categorized. The data that were not related to the research were reduced and the related ones were used and displayed. Finally, the conclusion can be drawn.

\section{Findings and Discussion}

Schools should be a place for learning, playing, and developing students' creativity so that the learning process can be fun. Creative schools cultivate talents based on student interests with a humanist approach so that these talents can be appropriately channeled and developed. Creative schools produce innovative and creative ideas based on a school development concept that utilizes edutainment strategies. Based on the data of interview and observation, the present study revealed that the NU MASTER Elementary School uses edutainment strategies in building students' character at the school. As the previous research stated that edutainment means integrating education and entertainment in the learning process (Corona, et.al., 2013; Corona, et.al., 2011). This finding is also in line with Lestari, et al. (2021) who state that elementary school should enhance the education through building students' character. Septiani, et al. (2020) explain that students character that is 
good and strong play an important role for their behavior and social life. The programs of the school engage the students to learn in fun and enjoyable atmosphere within shaping their character at school. This result is in line with Kurniawan (2016), who declares that school should be an enjoyable place for children, so they feel comfortable to stay at school.

A fun and creative school cannot be separated from creative and professional teachers. In the teaching and learning process, the key lies in the teacher who is in control of the class, because as the class director, the teacher determines whether the class can stay exciting. Tripathi et al (2018) point out, 'the quality of education is directly connected to the quality of instruction' (p.1455). Especially, inside the classroom, the teacher must be able to master the class and provide motivation for students. As stated by the school principal in the interview,

Transcript of interview 1:

P: 'Every student is a good child and only needs to be given proper attention, affection, and direction. So, the teachers have to be creative who are required to be imaginative and innovative in the teaching and learning process in the classroom. This aims to make students will not get quickly bored with the material provided and can participate in learning with a happy heart.'

With creative learning that is full of innovation, the learning process will run smoothly and pleasantly. The teacher's creativity is highly required in the classroom. Teachers must avoid becoming the single ruler of the class, which creates a monotonous atmosphere. In line with this, Utami, et al. (2021) say that teachers must have quality of knowledge, skills and behavior as the main aspects in applying educational roles at schools. Therefore, creative teacher is very much needed, so learning in the classroom becomes fun.

Moreover, the observation result indicate that the NU Elementary School is a school full of innovation and ideas in developing students' characters. The activities held at school aim to generate creative students. In this school, not only knowledge is instilled in students, but character building is also emphasized. It can be seen from the behavior of students who always politely greet every time they meet with teachers and seniors. It means that the cultivation of character has been wellperformed, and character-building is carried out through school activities. This school also utilize the technological programs and digital tools in order to make learners enjoy. The existing generation is indicated that they are more interested in the various streams of information that include frequent interaction. It is also known that fun activities are able to increase problem solving, inductive reasoning, and engagement (Conklin, 2012). The various edutainment-based activities for shaping students' characters at the school are as follows:

\subsection{Tilawah and Tahfid Qur'an (Qur'an Recitation and Memorization)}

The first program based on the edutainment-based activities conducted by the school is Tilawah and Tahfid Qur'an. Tilawah (recitations) and Tahfid (memorization) are taught directly by competent teachers who have memorized the Qur'an (Hafidz). Learning is also conducted with a class system based on students' abilities. The teacher confirmed in the following interview,

Transcript of interview 2:

T1: 'This system is beneficial for students whose abilities are below their peers. This grouping is a good idea for learning recitations because, in the process of learning, students looks happy, and the implementation of recitations and tahfid Qur'an activities provide results that are in accordance with students' abilities as well as the institution's target.'

This program is designed for learning Qur'an in fun activities though grouping and creating environment like outside the class, such as in the library or in the park. This program creates students to have religiosity and high motivation in reciting Qur'an as a daily routine. This is in accordance with Ishak (2017), who states that the implementation of the Qur'an recitation program 
means encouraging people to read the Qur'an, and not merely use it as home decoration. In this learning process, the teacher uses edutainment strategies that are appropriate to recitation learning so that students do not simply explore recitations and the memorization of the Qur'an, but more. The school must ensure students' happiness in the learning process so that learning goals are properly and successfully achieved. The following figure displays this kind of activity.

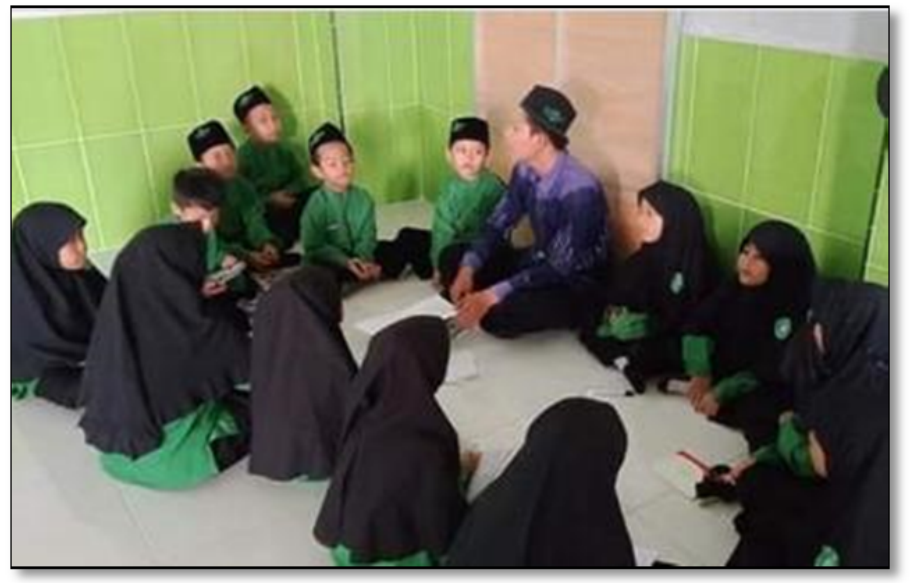

Figure 1: Tilawah and Tahfid Qur'an

In the Qur'an recitation activity, Ustadz (male teacher) invites students to the library to read the Qur'an correctly, so that students develop motivation to the reading activity and achieve the knowledge that is needed. The teacher formed the student's like-to-read character through collaboration with language laboratories or librarian so that the cooperation between Tilawah and Tahfidz Qur'an teachers runs well. The school also facilitates students to collaborate with parents by recording teachers' memorization as guidance for learning at home. Collaborative learning with parents pleases the students, and parents are also very happy for their children's success. The character formation carried out by the teacher does not bother students, as character-building is carried out imperceptibly in the form of playing and learning. Therefore, the concept of edutainment for creating students' character is applied.

\subsection{Multiple Language Program}

The next creative program to develop students' character at the school is providing multiple language activity for students. This program is as the language habituation carried out in the learning process. Particularly, the result of the interview shows in the following,

Transcript of interview 3:

T2: 'The students are accustomed to use English at school every Monday, Tuesday, and Wednesday. Thursday is for the Javanese language, and Friday is allocated for Arabic. Language habituation is carried out in morning routines by applying simple sentences (such as permission to go to the toilet, permission to leave the classroom, apologies and asking for help), and other vocabularies.'

This program aims to develop the students to have language proficiency. In other words, through multiple language, the students practice multiple language at school in order to improve their speaking in multiple language especially Indonesian, Javanese, English and Arabic. Similarly, 
Artiyana (2018) states that teachers play an essential role in getting children used to speak foreign language. Wahyuningsih and Afandi (2020) suggest that it can be conducted by providing practices through simultaneous communications. This activity encourages the students to have high motivation and interest in memorizing Arabic, Javanese and English. Besides, the students are habituated to be brave in practicing foreign language.

The principal considers that the school prepares the students' characters through fun ways to avoid boredom, as students must always be disciplined and responsible in the learning activities. As stated by the principal in the following,

Transcript of interview 4 :

P: 'The learning activities are designed to be fun, for example, through games and singing. The character-building, which the teacher does through activities like studying, playing, and singing, makes students appear interested in memorizing Arabic, the Javanese language, and English.'

According to the activity observed, the students look happy and enthusiastic, as perceived from the way they speak. The result of observation also shows that students become less awkward when hanging out and cooperating with friends, because, at school, they are also trained to enjoy reading so that language practice can be more fluent. Therefore, multiple language program is involved in the edutainment strategy for building student character as a concept that is suitable for creative schools.

\subsection{Computer Education}

The third program that develop students' character using edutainment based strategy is providing computer education from the early grade. In adapting to the advancement of an increasingly modern era, students and teachers are expected to follow global technology. The computer education is one of the school programs that aims to facilitate the students to master the technology as earlier as possible. This result is shown in the following figure.

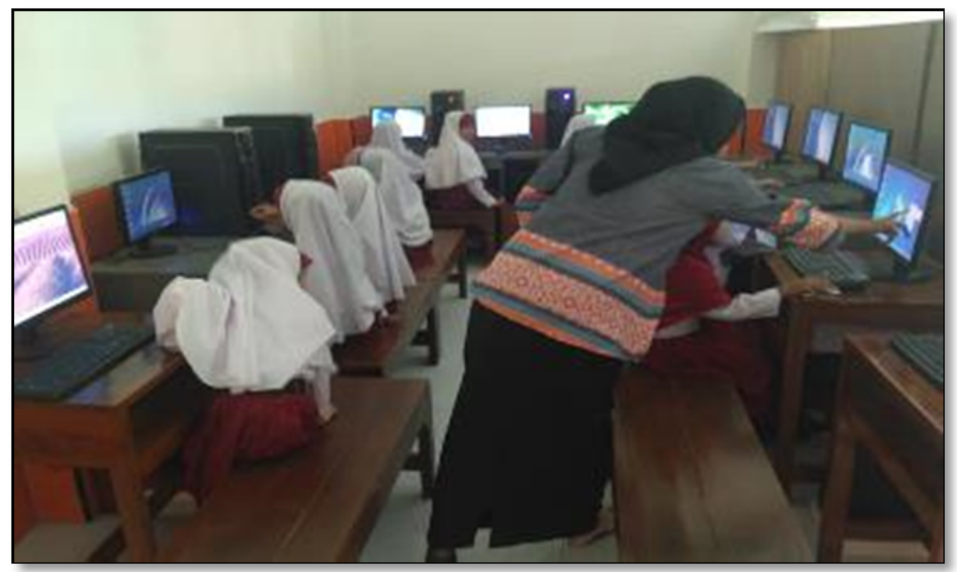

Figure 2: Computer Education

The students are familiarized with the academic main tool in this modern era, computer, which is as the important technology to help them in the future. Equally, Shinta et al. (2019) state that the development of technology and information can encourage efficiency and effectiveness for human life. Particularly, the whole aspects of life need technology, not to mention in education. Besides, this programs also purposes to build the students' character, namely their curiosity and creativity. These 
characters were built through various activities that are fun such as game, and tasks that demand the students to use their creativity. This finding is in line with Normawati (2016) that the teacher facilitates activities and assignments to students who use computers.

According to the interview, Ustadzah (female teacher) introduced computers in the first grade; then, students will be taught the next levels gradually according to their grade. This finding was stated by the teacher in the following interview result.

Transcript of interview 5:

T1: 'Activities and assignments given to each class are different. The higher the grade, the assignments and activities are more varied and complex. First and second-grade activities are typing and numeracy exercises. But the activities of third-grade students are typing, drawing, and internet browsing. Thirdgrade students can read and write fluently, so they mostly do activities involving typing assignments and internet browsing to develop reading skills.

Computer education is designed to be fun; for example, when a child can complete a task properly, then the child may play educational games on the computer. In addition, the teacher also provides game-based online learning services, namely Kahoot, as a medium for student evaluation. This game can be played online and is Android-users friendly. Thus, students are facilitated to study at home with Kahoot as the media, which also involves parents. The teacher believes that the aforementioned learning strategies will increase curiosity and creativity in students. Thus, introducing computer education at the elementary school involving fun activities is as an attempt to build students character.

\subsection{Outdoor Learning}

The next interesting program using edutainment based strategy for building students character at this school is outdoor learning for students. The school holds the outdoor learning activities once a month. This program is to support thematic learning in the elementary school as the suggested national curriculum in Indonesia in which the students study the authentic material and have meaningful experiences. In the same way, Husamah (2013) said that outdoor learning is a form of learning that invites students to study outside the classroom to see events directly in the field to familiarize students with their environment. The principal and the teachers explained that outdoor learning provided many benefits for students, as stated in the following interview results.

Transcript of interview 6:

\section{P: 'Outdoor learning makes students more enjoyable than learning in the classrooms.'}

T1: 'Outdoor learning has many advantages that greatly help students in the learning process such as outdoor learning can make students more interested in participating in various class activities.'

\section{T2: 'Applying this activity, students possess the responsibility of caring for the environment.'}

The teacher designs learning activities outside the classroom, such as in the field, to make students focus on real and tangible objects. Learning materials that fit into this strategy include types of plants (in natural science), artificial and natural topography, and traditional and modern markets for the environment (in social studies). Besides sciences, learning material on the religious study about God's creation is also taught through this strategy. The following figure describe the outdoor learning at NU MASTER Elementary School. 


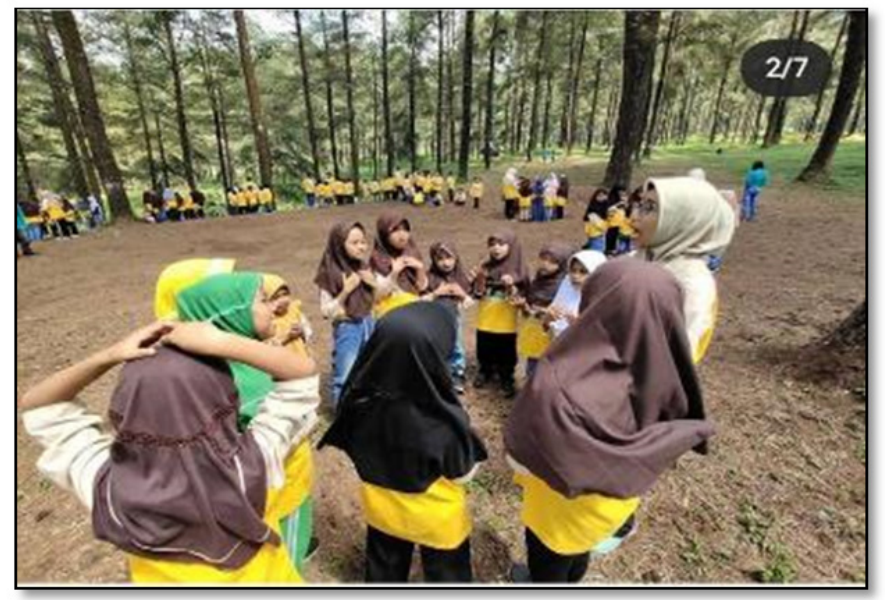

Figure 3: Outdoor Learning

Outside the classrooms, the environment can be used as a factual learning source because in the field students can directly encounter the materials they learned in the classroom. Danarti (2014) also suggested that through outdoor learning, students will gain knowledge that they personally discover through the formation of ideas, concepts, and knowledge through direct experience of seeing the learning objects. In the outdoor learning, the students observe the environment to gain their knowledge and to build their character directly. Likewise, Septiani, et al. (2020) suggest that applying observational learning can reinforce the students' character. Through this program, the students are fostered to have religiosity, responsibility and empathy. In short, at this school, outdoor learning aims to foster the character of students to care for the environment, so the students also understand the importance of cleanliness at school.

\subsection{Leadership and Entrepreneurship Program}

In addition, the school gives leadership and entrepreneurship program for their students in building their character over fun learning activities. In this program, the school hold a market day event once a month that the students are as the buyer and the seller. The activity is conducted alternately, for example, between first graders as sellers, and second and third graders as buyers.

The teacher confirmed that this activity can form honesty in students by encouraging them to convey accurate information to buyers; for example, about materials and prices from suppliers. In this activity, students collaborate with parents in the procurement of products. The buying and selling process is carried out at school during snack time, provided that snacks sold are healthy foods and drinks without MSG and artificial sweeteners. The interview result confirmed this finding as follow, Transcript of interview 7 :

P: 'The independence of students is automatically built through these activities.'

T1: 'The students learn about problem-solving through a democratic system by discussing it with their peers in achieving a fair decision.'

This activity is displayed in the following figure, 


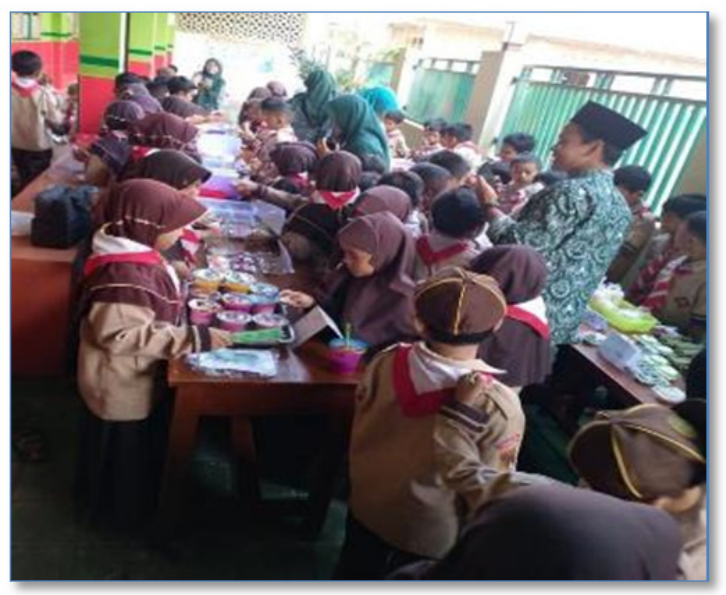

Figure 4: Leadership and Entrepreneurship Program

The students apply the principles of leadership, in this fun and enjoyable activity, namely responsible, independent, disciplined, socially caring, and honest. Besides, the students also practice problemsolving directly with the groups. This finding is according to Fitroh and Mayangsari (2017) that entrepreneurial leadership creativity appears in several aspects observed ranging from creativity, innovation, intuition, and motivation, as well as the courage to take risks. From five aspects above, motivation and creativity have the highest value. Motivation is having high involvement in the task and being happy while enjoying each learning activity. Whereas creative is the ability to think smoothly and flexibly. In this program, parents help the students to prepare the goods to be sold in the market. In other words, all the components are involved in this program to support the students to have wonderment characters. This result is in line with Hermino and Arifin (2020) who state that teachers, parents, religious leaders and community leaders have important role for promoting morals, role models and positive motivation for building students' character.

\subsection{Inviting Native Speaker}

Lastly, inviting native speaker to the school is as the edutainment program at the school to build students' character. By welcoming native speakers, students are provided an opportunity to communicate directly with native speakers using simple conversations that have been taught by teachers in multiple language learning. The schedule for its arrival has been determined at every beginning of study year. This school offers the formation of friendly and communicative characters that is accomplished in a fun and innovative way. Students are presented with a chance to communicate in Arabic and English-languages set by the school. The principal stated the advantages of the program in the following interview result.

Transcript of interview 8:

P: 'This activity gives advantages as native speakers provide the correct way to pronounce a foreign language and expose students to the various dialects of the language. This program may give an excellent experience for students and teachers.'

As from the observation result, the invited native speakers to provide learning material and communicate with students through singing and playing strategies, and the students looks engaged. The following figure shows the students' activity in this program. 


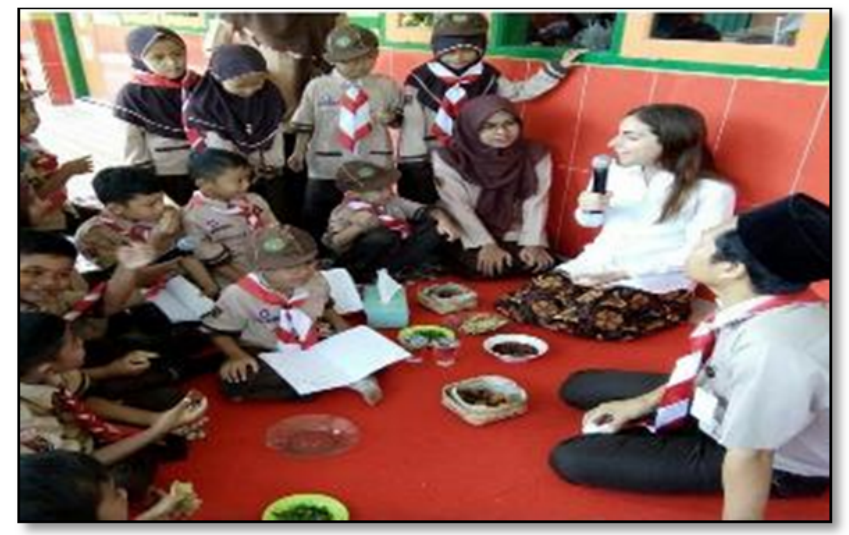

Figure 5: Inviting Native Speakers

The students learn Arabic or English directly from the native speakers in which it can improve students' motivation. This language learning process is provided in the fun and innovative way, so that the students feel enjoy. Likewise, Yusuf and Anwar (1995) proposed that bringing native Arabic speakers (alnâthiq al-ashlî) as the main instructor will be meaningful for the child. The students have meaningful experience in conducting this program. The character that were developed from this activity was that the students became brave and confident.

\section{Conclusion and Implications}

Creative schools possess innovative, creative ideas and conceptions using the edutainment strategy. The edutainment programs are developed variously at NU Master Elementary School. Firstly, the school provides Tilawah and Tahfid Qur'an (Qur'an recitation and memorization) that are taught in the fun and enjoyable activities in order to form students character to like reading Qur'an. Next, the school implements multiple language practices to habituate the students using multi language; besides, the teachers formed various student's characters, namely friendly, communicative, as well as disciplined and responsible. Thirdly, the students receive computer subject from the early grade, that are taught in fun and enjoyable activities that aims to increase students' curiosity and creativity. The fourth program is that the school always provide outdoor learning activity such as by bringing the student outside the class in the field for shaping the character of students: including caring for the environment, responsible, religious, and disciplined. Then, the principles of leadership are given in the annual program, for example a market day event is held as a form of entrepreneurship learning including character of responsible, independent, disciplined, socially caring, and honest. Lastly, inviting native speaker is one of the great programs at the school in which the students had chance to communicate directly with native speakers so that the students become friendly, communicative and creative.

Therefore, the elementary school as the early education should consider character education for their students, especially, creating various activities to make students habituated from school. Particularly, the school should design each learning activity according to the students' needs such as young learner characteristic whose activities are mostly fun and enjoyable. Besides, because current generation are the millennial who can be fast and independent learner, teachers should provide interesting learning activities to improve their own potential. In short, edutainment is one of effective methods to build students' character at school which is appropriate for young learners. 


\section{References}

Artiyana, R. N. (2018). Implementasi program Bahasa Inggris di SDIT Lukman Al Hakim Internasional. Jurnal Pendidikan Guru Sekolah Dasar, 7(8). http://journal.student.uny.ac.id.

Asmani, J. M. (2011). Buku Panduan Pendidikan Karakter di Sekolahan. Yogyakarta: Diva Press.

Conklin, T. (2012). Making it personal: The importance of student experience in creating autonomy-supportive classrooms for millennial learners. Journal of Management Education, 37(4), 499-538.

Choli, I. \& Raihan, (2020). Factors that Influences The Character of Student in The School, Journal of Educational and Social Research 10(3), 105-114

Corona, F., Cozzarelli, C., Palumbo, C., \& Sibilio, M. (2013). Information technology and edutainment: Education and Entertainment in the age of interactivity. International Journal of Digital Literacy and Digital Competence, 4(1), 12-18. DOI:10.4018/jdldc.2013010102

Corona, F., Perrotta, F., Polcini, E. T. \& Cozzarelli, C. (2011). The New Frontiers of Edutainment: The Development of an Educational and Socio-Cultural Phenomenon Over time of Globalization. Journal of Social Sciences, 7(3), 408-411. https://doi.org/10.3844/jssp.2011.408.411

Danarti, R. (2014). Perbedaan hasil belajar IPS model Project Based Learning berbasis outdoor study dengan konvensional Siswa SMP. Jurnal Pendidikan Humiora, http://journal.um.ac.id/index.php/jph/article/view/4449/931.

Farida, A., \& Suhud R. (2014). Sekolah yang Menyenangkan: Metode Kreatif Mengajar dan Pengembangan Karakter Siswa. Bandung: Nuansa Cendikia.

Fitroh, S. F., \& Dewi M. (2017). Kreativitas Entrepreneurial Leadership dalam Pembelajaran Kewirausahaan Pada Anak Usia Dini. Jurnal Pendidikan Guru Sekolah Dasar, 6(2). http://journal.student.uny.ac.id.

Hamruni. (2013). Pembelajaran Berbasis Edutainment: Landasan Teori dan Metode-metode Pembelajaran Aktif Menyenangkan (PAIKEM). Yogyakarta: Fakultas Ilmu Tarbiyah dan Keguruan UIN Sunan Kalijaga.

Hermino, A., \& Arifin, I. (2020). Contextual character education for students in the senior high school. European Journal of Educational Research, 9(3), 1009-1023. https://doi.org/10.12973/eu-jer.9.3.1009

Herpratiwi, Setiyadi, B., Riswandini, Ertikoanto, C., \& Sugiyanto. (2018). Building Students' Character in Elementary School through the Scientific Method: A Case Study of the Lampung Province. Pertanika Journal of Social Sciences and Humanities, 26(1), 1547-1561. http://www.pertanika.upm.edu.my/pjssh/browse/regular-issue?article=JSSH1924-2016

Husamah. (2013). Pembelajaran Luar Kelas Outdoor Learning. Surabaya: Prestasi Pustaka Raya.

Ishak, M., Syafaruddin, \& Sit, M. (2017). Pelaksanaan program tilawah Al Qur'an dalam meningkatkan kemampuan membaca Al Qur'an Siswa di Mas Al Ma'sum Stabat. Edu Riligia: Jurnal Ilmu Pendidikan Islam dan Keagamaan, 1(4). http://jurnal.uinsu.ac.id.

Katsaliaki, K., \& Mustafee, N. (2014). Edutainment for Sustainable Development: A Survey of Games in the Field. SagePub.com

Kesuma, D. (2012). Pendidikan Karakter Kajian Teori dan Praktik di Sekolah. Bandung: PT Remaja Rosdakarya.

Kurniawan, H. (2016). Sekolah Kreatif: Sekolah Kehidupan Menyenagkan untuk Anak. Yogyakarta: Ar Ruzz Media.

Kusmarini, Y., Winarti, M., \& Kurniawati, Y. (2016). The Development of Edutainment Learning Model in Social Science Education/IPS: Research and Development Study on IPS Education at Elementary Level in Bandung and Cimahi. International Journal of Pedagogy of Social Science, 2(1). https://doi.org/10.17509/ijposs.vii2.4771

Lestari, F. P., Ahmadi, F., \& Rochmad, R. (2021). The implementation of mathematics comic through contextual teaching and learning to improve critical thinking ability and character. European Journal of Educational Research, 10(1), 497-508. https://doi.org/10.12973/eu-jer.10.1.497

Lickona, T. (1991). Educating for Character: How Our Schools Can Teach Respect and Responsibility. New York: Bantam Books.

Makarius, E.E. (2016). Edutainment: Using technology to enhance the management learner experience. Sage Journal, 2(1), 17-25. https://doi.org/10.1177/23792981166806oo.

Musthan, Z. (2019). An Effective Leadership Model for Madrasah Principals in Indonesia. Pertanika Journal of Social Sciences and Humanities, 27(1), 133-147. http://www.pertanika.upm.edu.my/pjssh/browse/regularissue?article=JSSH-3753-2018

Ningsih, T. (2020). Mental revolution education strategy in realizing child-friendly schools based on character education strengthening. Akademika: Journal of Southeast Asia Social Sciences and Humanities, 9o(1), 113122.

Normawati, N. (2016). Pemanfaatan komputer dalam pembelajaran di SD Negeri Tukangan Yogyakarta. Jurnal Pendidikan Guru Sekolah Dasar, 5(23). http://journal.student.uny.ac.id. 
Nurhayati, R. (2017). Indikator Sekolah Kreatif. Jurnal Pembangunan Pendidikan: Fondasi dan Aplikasi, 5(2). http://journal.uny.ac.id/index.php/jppfa.

Pangastuti, R. (2014). Edutainment PAUD. Yogyakarta: Pustaka Pelajar.

Rofiah, N.H. (2014). Edutaiment dalam Active Learning pada Implementasi Kurikulum 2013 di Sekolah Dasar. Universitas Ahmad Dahlan. http://eprints.uad.ac.id/2958/

Rusydi, N.A. (2017). The Influence of the Implementation of Edutainment Method in Learning on Social Science Learning Results at SD Kartika Xx-I in Mamajang Sub-District of Makassar City (Thesis). Universitas Negeri Makasar. http://eprints.unm.ac.id/438o/1/Nur\%2oAlfyfadhilah\%2orusydi.pdf

Samawi \& Hariyanto. (2011). Konsep dan Model Pendidikan Karakter. Bandung: Remaja Rosdakarya.

Saripudin, A., \& Isnaeni, Y. F. (2018). Strategi edutainment dalam pembelajaran di PAUD (Studi Kasus pada TK di Kota Cirebon). AWLADY: Jurnal Pendidikan Anak, 4(1). www.syekhnurjati.ac.id/jurnal/index.php/awlady.

Septiani, A. N. S. I., Rejekiningsih, T., Triyanto \& Rusnaini (2020). Development of interactive multimedia learning courseware to strengthen students' character. European Journal of Educational Research, 9(3), 1267-1279. https://doi.org/10.12973/eu-jer.9.3.1267

Sugiono. (2011). Metode Penelitian Kuantitatif, Kualitatif, dan R \& D. Bandung: Alfabeta.

Tripathi, A., Chaturvedi, K.R., \& Tripathi, A.P. (2018). Assessing the Influence of Intrinsic Motivation on Academic Performance: A Study of Management Teachers. Pertanika Journal of Social Sciences and Humanities, 26(3). 1455-147o. http://www.pertanika.upm.edu.my/pjssh/browse/regular-issue?article=JSSH-1887-2016

Yusuf, T., \& Anwar, S. (1995). Metodologi Pengajaran Agama dan Bahasa Arab. Depok: Raja Grafindo Persada. 